\title{
Rhétorique et compétence ordinaire : le cas de l' inventio
}

Sebastian T. McEvoy

\section{OpenEdition}

\section{Journals}

Édition électronique

URL : http://journals.openedition.org/shakespeare/1235

DOI : 10.4000/shakespeare.1235

ISSN : 2271-6424

Éditeur

Société Française Shakespeare

Édition imprimée

Date de publication : 1 novembre 1992

Pagination : 117-124

Référence électronique

Sebastian T. McEvoy, "Rhétorique et compétence ordinaire : le cas de l'inventio », Actes des congrès de la Société française Shakespeare [En ligne], 10 | 1992, mis en ligne le 01 janvier 2007, consulté le 25 avril 2019. URL : http://journals.openedition.org/shakespeare/1235; DOI : 10.4000/shakespeare.1235

Ce document a été généré automatiquement le 25 avril 2019

(C) SFS 


\title{
Rhétorique et compétence ordinaire : le cas de l'inventio
}

\author{
Sebastian T. McEvoy
}

